\title{
PANDANGAN MANGKUNEGARA IV TENTANG SUFISME DAN FIQH
}

\author{
Hafid
}

STAI Al-Hamidiyah Bangkalan

Email: hafidhsahlan@gmail.com

\begin{abstract}
Mangkunegara IV thought, about four types of worship, among others; worship, caution (heart), worshiping the soul, the flavor is a synchronization between fiqh reasoning with sufism. His thoughts on the model of the application of the Shari'a of the Prophet (s), in harmony with the Mahmud Salthut, Shah Waliyullah, Ibn 'Abbad, and al-Kalabadzi, and the naqliah arguments which are used as references. The worldview of Sufism and Fiqh keeps the Qur'an and Hadith as a reference, but there are differences on the priority scale, Sufism is more emphasis on the inner aspect, while the Fiqh are more in the external aspect. At this point, Sufism and Fiqh are often different about the concept of right and wrong, and of course differ in the treatment of people of differing opinions, both within the same religious community, let alone different ones.
\end{abstract}

Keywords: Mangkunegara IV, Worship, Sufism, Fiqh

\begin{abstract}
ABSTRAK
Mangkunegara IV berpikir, tentang empat jenis ibadah, antara lain; ibadah, hati (hati), penyembahan jiwa, rasanya adalah sinkronisasi antara penalaran fiqh dengan sufisme. Pemikirannya tentang model penerapan Syariah Nabi (s), selaras dengan Mahmud Salthut, Shah Waliyullah, Ibn 'Abbad, dan al-Kalabadzi, dan argumen naqliah yang digunakan sebagai referensi. Pandangan dunia tasawuf dan Fiqh menjadikan Alquran dan Hadis sebagai referensi, tetapi ada perbedaan pada skala prioritas, tasawuf lebih menekankan pada aspek batin, sedangkan Fiqh lebih pada aspek eksternal. Pada titik ini, Sufisme dan Fiqh sering berbeda tentang konsep benar dan salah, dan tentu saja berbeda dalam perlakuan orang-orang yang berbeda pendapat, baik dalam komunitas agama yang sama, apalagi yang berbeda.
\end{abstract}

Kata kunci: Mangkunegara IV, Ibadah, Sufisme, Fiqih

\section{PENDAHULUAN}

Menurut Paul Nwiya ${ }^{1}$, dalam menjalankan wahyu Allah, kaum Sufi berupaya menginteriorisasikan respon mereka kepada Allah, dan memupuk dalam diri mereka sendiri kesadaran yang lebih tajam akan perubahan-perubahan yang ditimbulkan oleh interiorisasi dalam kedalaman maujud-maujud mereka ini. Mereka menggunakan bahasa Al-Qur'an untuk mengungkapkan penemuan-penemuan baru mereka, dan juga mengembangkan hermeneutik simbolis, yang berbeda dengan literasi faqih ${ }^{2}$.

\footnotetext{
${ }^{1}$ Dr. Paul Nwiya yang memberikan tulisan sambutan pada karya Adonis (Ali Ahmad Sa'id Asbar) IV jilid, yang berjudul Arkeologi Sejarah-Pemikiran Arab-Islam, terbitan LKiS, 2007.

${ }_{2}$ Muhammad Ibn"Abbad, Letter On The Sufi Parth (terj.) M.S. Nasrullah, Surat-Surat Sang Sufi (Bangdung: Mizan,1993), 45
} 
Kaum Sufi dan Ahli fiqh memusatkan perhatian mereka pada data wahyu yang sama, tetapi mereka menggunakan model-model pengungkapan yang berbeda untuk menggambarkan temuan mereka. Menurut Nwiya, temuan kaum Sufi tersebut, baik dalam Al-Qur'an maupun dalam tanda-tanda Allah pada ciptaan secara keseluruhan, dapat ditemukan makna batiniah yang implikasi-implikasinya jauh melampaui implikasi-implikasi makna lahiriah. Sedangkan bagi Ahli fiqh, tidak lebih Al-Qur'an dikaji untuk menunjang aspek aturan hidup yang bersifat lahiriah semata.

\section{SUFISME DAN FIQH MENURUT MANGKUNEGARA IV; UPAYA MENEMUKAN TITIK TEMU}

Mangkunegara IV ${ }^{3}$ (1811-1881) seorang tokoh Sufi dan mempunyai berbagai bidang keahlian. ${ }^{4}$ Dari sekian keahliannya yang paling monumental tentang pemikirannya yang ditulis dalam serat, diantarnya; Serat-serat Piwulang, Darmalaksika, dan Wedatama.

Ajarannya tentang tasawuf meliputi dua hal, yaitu; Sembah budiluhur. Pengertian sembah dan ajaran Mangkunegara adalah terjemahan darikata ibadah yang diambil dari al-Qur'an dan Hadith. Terdapat empat sembah dalam ajarannya, antara lain $;^{5}$

\footnotetext{
${ }^{3}$ Kanjeng Gusti Pangeran Adipati Arya Mangkunegara IV (KGPAA Mangkunegara IV) lahir pada tanggal 3 Maret 1811 (Senin Pahing, 8 Sapar 1738 tahun Jawa Jumakir, Windu Sancaya) dengan nama kecil Raden Mas Sudira. Ayahnya bernama KPH Adiwijaya I sementara ibunya adalah putri KGPAA Mangkunagara II bernama Raden Ajeng Sekeli. Oleh karena KPH Adiwijaya I adalah putera Raden Mas Tumenggung Kusumadiningrat yang menjadi menantu Sri Susuhunan Pakubuwono III, sedangkan R.A Sekeli adalah puteri dari KGPAA Mangkunagara II, maka secara garis keturunan R.M. Sudira silsilahnya adalah sebagai cucu dari KGPAA Mangkunagara II dan cicit dari Sri Susuhunan Pakubuwono III. Selain itu ia merupakan cicit dari K.P.A. Adiwijaya Kartasura yang terkenal dengan sebutan Pangeran Seda ing Lepen Abu yang gugur ketika melawan Kompeni Belanda. Masa pemerintahannya adalah sejak 1853 hingga wafatnya 1881. Pada masa pemerintahannya, pihak istana Mangkunegaran menulis kurang lebih 42 buku, di antaranya $\underline{S e r a t ~ W e d h a t a m a, ~ d a n ~ b e b e r a p a ~ k o m p o s i s i ~ g a m e l a n . ~ S a l a h ~ s a t u ~ k a r y a ~ k o m p o s i s i n y a ~}$ yang terkenal adalah Ketawang Puspawarna, yang turut dikirim ke luar angkasa melalui Piringan Emas Voyager di dalam pesawat antariksa nirawak Voyager I tahun 1977. Atas jasa kepujanggaannya, khususnya dalam penulisan Serat Wedhatama, MN IV mendapat penghargaan Bintang Mahaputra Adipradana dari Pemerintah RI melalui Keppres RI nr. 33/TK/Tahun 2010 secara anumerta, yang diberikan oleh Presiden Susilo Bambang Yudhoyono kepada perwakilan kerabatnya pada tanggal 3 November 2010. MN IV wafat tahun 1881 dan dikebumikan di Astana Girilayu. Dapat dikatakan bahwa pada masa pemerintahannya, Mangkunagaran berada pada puncak kebesarannya. https://id.wikipedia.org/wiki/Mangkunegara_IV, diakses tanggal 24 Oktober 2017

${ }^{4}$ Antara lain: kenegaraan, kemiliteran,sastra budaya,dan keagamaan. Lihat di Moh. Ardani, al-Qur'an dan Sufisme Mangkunegara IV (Studi Serat-serat Piwulang), (Yogyakarta: Dana Bhakti Wakaf, 1995), 1

${ }^{5}$ Ibid, 56-95
} 
1. Sembah raga, yaitu menyembah Tuhan dengan mengutamakan gerak laku badaniyah, atau amal perbuatan yang bersifat lahiriyah. Sembah ini, disucikan dengan cara wudlu. Sembah raga tersebut, meskipun lebih menekankan gerak laku badaniah, namun bukan berarti mengabaikan aspek rohaniah. Sebab orang yang magang laku, selain ia menghadirkan seperangkat fisiknya, ia juga menghadirkan seperangkat aspek spiritualnya, hingga meningkat ke tahap kerohanian yang lebih tinggi.

2. Sembah cipta (kalbu), yaitu menyembah Tuhan dengan lebih mengutamakan peranan kalbu. Sembah kalbu lebih menitik beratkan kebersihan dan kesucian kalbu dari sifat-sifat yang mengotori hati. Sembah ini disucikan dengan memperkecil keinginan hawa nafsu dalam bentuk taharah batiniah.

3. Sembah jiwa, yaitu sembah kepada Allah dengan mengutamakan peran jiwa atau ruh. Menurut Mangkunegara IV, sembah ini hendaklah diresapi secara menyeluruh tanpa henti setiap hari. Sembah ini juga disebut pokok tujuan atau akhir perjalanan suluk. Cara bersucinya dengan awas emut (selalu waspada dan ingat/zikir) kepada keadaan alam baka (langgeng), alam ilahi.

4. Sembah rasa, yaitu sembah yang dihayati dengan merasakan intisari kehidupan makhluk semesta alam, didasarkan pada rasa semesta. Sembah rasa berarti menyembah Tuhan dengan menggunakan alat batin inti ruh, alat batin yang paling dalam dan paling halus yang menurut Mangkunegara IV disebut telenging kalbu (lubuk hati yang paling dalam) atau wosing jiwangga (inti ruh yang paling halus). Pelaksanaan sembah rasa ini tidak lagi memerlukan petunjuk dan bimbingan guru seperti ketiga sembah sebelumnya, tetapi harus dilakukan salik sendiri dengan kekuatan batin.

Ajaran lainnya, mengenai budiluhur adalah akhlak atau budi pekerti yang terpuji dalam masyarakat manusia sepanjang masa. Menurutnya, budiluhur mempunyai kedudukan yang amat penting di samping sembah. Keduanya berpadu kait berkait sebagai satu kesatuan yang utuh. Budiluhur juga bergantung pada sembah yang baik. Sembah raga dihayati dengan sembah kalbu, jiwa, dan rasa membuat seseorang berkemampuan tinggi dalam menguasai hawa nafsu dan berbagai budipekerti tercela. 
Ajaran budiluhur Mangkunegara IV ini senada dengan Mahmud Shaltut, yang menyatakan bahwa hakikat agama adalah pergaulan. Dan hakikat agama dalam pergaulan adalah baiknya budi pekerti. Ajaran ibadat terkait erat dengan ajaran budi luhur. ${ }^{6}$

Pada point ajaran Mangkunegara IV tentang budiluhur inilah yang dapat disinkronkan dengan fiqh. Menurutnya, dalam mematuhi agama, hendaknya seseorang tidak berpaku pada syari' at yang bersifat lahiriah, perlu memahami al-Qur' an dan Hadith yang menjadi landasan dasar ijma'dan qiyas. Yang pada intinya, penghayatannya menggabungkan yang lahiriah dan batiniah sekaligus sebagaimana dalam penjelasan empat sembah.

Selanjutnya dalam meneladani Rasul, mengingat kondisi ruang dan waktu khususnya di Jawa, maka jejak langkah perihidup Rasulullah SAW tidak perlu contoh secara keseluruhan, tetapi cukup sedikit saja asal yang inti dan pokok. ${ }^{7}$ Menurut Mangkunegara IV, Jawa yang mempunyai sifat sendiri dan masyarakatnya yang non Arab, tidak akan mampu meniru perilaku rasulullah secara menyeluruh. Pada diri Nabi Muhammad SAW, melekat dua unsur kerasulan dan ke-Arab-an. Sebagai Nabi penutup beliau ditugasi membawa wahyu dan risalah yang berisi pokok-pokok akidah, ibadah, dan akhlak yang berlaku sepanjang masa dan wajib diteladani (meskipun merupakan contoh yang baik diikuti apabila ada kesanggupan). Oleh karena itu, orang Jawa yang bukan Arab, karena kurang adanya kesanggupan, lebih baik meneladani contoh yang pertama, meski sedikit porsinya.

Mangkunegara IV juga mengatakan bahwa tidak pantas seseorang mencari pujian dengan mengamalkan seluruh hukum fiqh yang banyak diantaranya berorientasi kepada unsur ke-Arab-an. Ia menegaskan bahwa tidak perlu mencontoh persis seperti yang ada dalam fiqh, tetapi cukuplah seseorang mengamalkan inti pokoknya, sesuai dengan unsur yang pertama tentang pokok isi risalah. Inti sari fiqh yang demikian, biarpun sedikit jumlahnya, apabila dilaksanakan dengan segala kesungguhan hati, akan cukup memadai dan akan mendatangkan rahmat. ${ }^{8}$

\footnotetext{
${ }^{6}$ Mahmud Shaltut, Al-Islam Aqidah wa Shari'ah (Mesiri: Dar Al-Qalam,1996), 95

${ }^{7}$ Moh. Ardani, Al-Qur'an....., 153

${ }^{8}$ Ibid, 154
} 
Bertolak dari kenyataan bahwa Islam di negeri ini begitu jauh jarak, ruang dan waktunya dari negeri asalnya, di samping melekatnya sifat kejawaan yang tidak sama dengan sifat ke-Arab-an, Mangkunegara IV mengkhawatirkan kesanggupan bangsa yang non-Arab ini dalam meneladani perilaku Nabi Muhammad SAW secara keseluruhan. Oleh karena itu, ia hanya mempfokuskan pada intitugas risalah Nabi.

Inti tugas risalah Nabi ini juga dibahas oleh Mahmud Shaltut, bahwa ia hanya merupakan sebagian kecil dari keseluruhan perilaku hidupnya yang dikenal sebagai sunnah, Shaltut membedakan Sunnah yang wajib diteladani dan yang tidak wajib diteladani. Yang pertama, adalah sunnah yang bertalian dengan tugas kerasulannya, yang menyangkut pokok-pokok akidah, ibadah, akhlak, dan penentuan apa yang halal dan haram. Yang kedua, adalah Sunnah yang bertalian dengan prilaku hidup manusia biasa dalam keseharian, yang bertalian dengan pengalaman hidup, percobaan yang ia lakukan, dan yang bertalian dengan cara-cara yang ia tempuh dalam menghadapi sistuasi khusus yang cukup pelik. Sunnah yang kedua ini tidak wajib dipatuhi, walaupun merupakan contoh yang baik. ${ }^{9}$

Pendapat tersebut sejalan dengan pendapat Syah Waliyullah seorang tokoh ulama India. Menurutnya, Islam mengandung ajaran yang bersifat universal dan yang bersifat lokal. Ajaran Islam yang univesal mengandung ajaran dasar. Sedangkan yang bersifat lokal mempunyai corak yang ditentukan oleh sistuasi dan kondisi setempat. Ini berarti bahwa Islam dapat disesuaikan pemahamannya dengan situasi setempat dan dengan kebutuhan zaman. ${ }^{10}$ Yang harus dipegang adalah ajaran dasar universal, sedangkan ajaran Islam yang lokal dapat ditinggalkan.

Tidak jauh berbeda dengan apa yang diungkapkan oleh Ibnu 'Abbad bahwa saat ini konteksnya telah sedikit berubah. Zaman pasca Nabi merupakan zaman dimana pembaharuan memerlukan perjuangan terus-menerus. Pada tingkat temporal, pembaharuan bergantung kepada pembaharuan Agama, dengan memperhatikan kebutuhan-kebutuhan nyata masyarakat luas. ${ }^{11} \mathrm{Ibnu}$ 'Abbad menilai, bahwa para ahli

\footnotetext{
${ }^{9}$ Mahmud Shaltut, al-Islam.....,510

${ }^{10}$ Harun Nasution, Pembaharuan dalam Islam (Jakarta: Bulan Bintang,1973), 22

${ }^{11}$ Muhammad Ibn 'Abbad, Letters...., 27-29
} 
fiqh semasanya hanya menempuh pemahaman lewat penggunaan akal dan pandanganpandangan kaku, yang semuanya itu merupakan langkah mundur dan tidak tepat. ${ }^{12}$

Sebagaimana juga dituturkan oleh al-Kalabadzi, bahwa perbedaan dalam menghasilkan fiqh/ijtihad, sepanjang hanya dalam masalah-masalah detil yang tidak penting dan masing-masing mengikuti ketentuan prinsipnya, maka semuanya benar. ${ }^{13}$

Ajaran Mangkunegara IV sebagaimana dipaparkan diatas, berkesesuaian dengan QS. Al-Baqarah (2) ayat: 286. yang Artinya: “Allah tidak membebani seseorang melainkan sesuai dengan kesanggupannya".

Berdasarkan Hadith Nabi SAW.

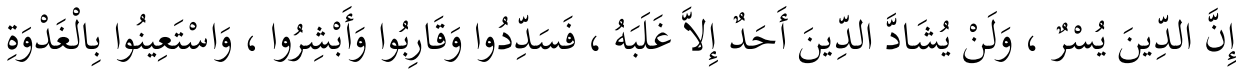

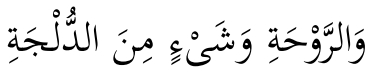

Artinya: "Sesungguhnya agama itu mudah, dan sekali-kali tidaklah seseorang memperberat agama melainkan akan dikalahkan, dan (dalam beramal) hendaklah pertengahan (yaitu tidak melebihi dan tidak mengurangi), bergembiralah kalian, serta mohonlah pertolongan (didalam ketaatan kepada Allah) dengan amal-amal kalian pada waktu kalian bersemangat dan giat". 14

Al-Bukhari Rahimahullah berkata:

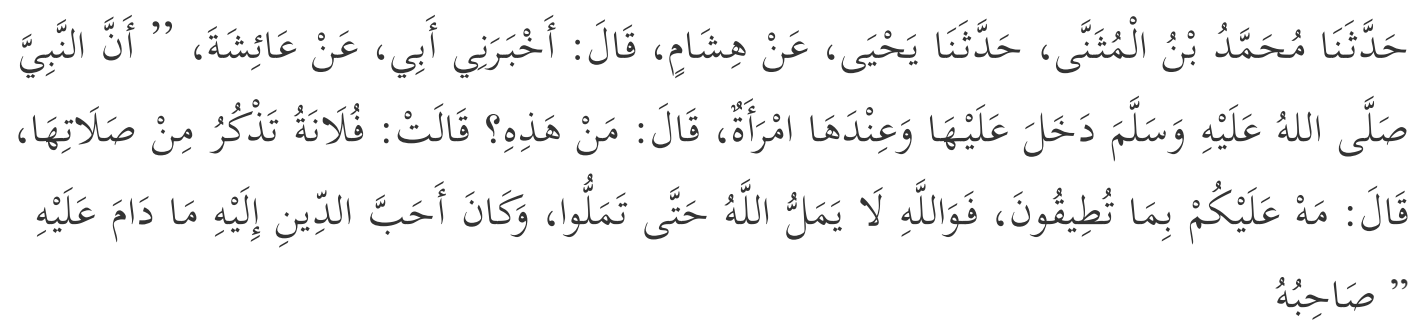

Artinya: "Telah menceritakan kepada kami Muhammad bin Al-Mutsannaa: Telah menceritakan kepada kami Yahyaa, dari Hisyaam,ia berkata: Telah mengkhabarkan kepadaku ayahku, dari 'Aaisyah: Bahwasannya Nabi Shallallaahu 'alaihi wa sallam pernah masuk menemuinya yang waktu itu di sebelahnya ada seorang wanita. Beliau Shallallaahu 'alaihi wa sallambersabda, 'Siapakah ini ?”.

\footnotetext{
12 Ibid, 76

13 Al-Kalabadzi, al-Ta'aruf li Mazahib Ahlal-Tasawuf (terj.) Rahmani Astuti, Ajaran Kaum Sufi (Bandung: Mizan, 1993), 101

${ }^{14} \mathrm{HR}$. Abu Hurairah
} 
Aisyah berkata, "Fulaanah". Lalu ia (Aisyah) menyebutkan tentang shalatnya (yang banyak dan lama). Beliau Shallallaahu 'alaihi wa sallam, "Ah, wajib bagimu beramal sesuai dengan kemampuanmu. Demi Allah, Allah tidak akan bosan hingga kalian bosan. Agama yang paling dicintai oleh Allah adalah yang dirutinkan oleh pelakunya. $" 15$

Berdasarkan prinsip hukum Islam:

$$
\begin{aligned}
& \text { ان الاحكام المتي يذشا عن تطبيقها حرج على المهكلف ومششة فى نفسه او ماله فالشريعة } \\
& \text { تخففهما بما يقع تحت قدرة الممكلف دون عسر او خرج }
\end{aligned}
$$

Artinya: "Hukum yang praktiknya menyulitkan mukallaf, dan pada diri dan sekitarnya terdapat kesulitan, maka syari'at meringankannya sehingga bebab tersebut berada di bawah kemampuan mukallaf tanpa kesulitan dan kesusahan".16

Hukum Shara' menekankan asas memberi kemudahan dan kelonggaran, tidak memberatkan, tidak banyak beban, dan pelaksanaannya secara bertahap. ${ }^{17}$ Sebagaimana metode Ibn"Arabi dalam mengimplementasikan shari' at yang menggunakan grand idea "kasih sayang Tuhan", yaitu bahwa hanya hukum-hukum yang dihasilkan dari ajaranajaran dan pengetahuan yang diinformasikan secara langsung oleh Tuhan-lah yang akan menjelmakan kasih sayang Tuhan, yaitu hukum-hukum yang tidak menyulitkan, tidak memberatkan, memberikan kelapangan, kemudahan,dan akhirnya kebahagiaan. ${ }^{18}$ Dalam prakteknya ketika membahas permasalahan syari'at, pertama ia membahas semua persoalan hukum fiqh satu persatu untuk dicarikan jawabannya berdasarkan argumentasi teori-teori dan metodologi hukum Islam formal, yang ia sebut sebagai pembahasan dari segi eksternal, kemudian fungsi, dan kedudukan batiniah dari semua aturan hukum fiqh tersebut dianalisis dan dikaitkan dengan keberadaan jiwa spiritual manusia.

Dari perbandingan di atas, dapat terlihat bahwa pemikiran Mangkunegara IV tersebut menunjukkan suatu pola pikir yang lebih realistis, manusiawi, dan lebih menjamin kelestarian amal, namun tetap sejalan dengan semangat ajaran shari'at.

\footnotetext{
15 Shahih Al-Bukhari no. 43

${ }^{16}$ Jaih Mubarak, Kaidah Fiqh: Sejarah dan Kaidah Asasi (Jakarta: Raja Grafindo, 2002), 139

17 Hudhari Bik, Tarikh Tashri' al-Islami (terj) Mohammad Zuhri, Sejarah Pembinaan Hukum Islam, (Semarang: Darul Ikhya, 1980), 402

${ }^{18}$ Nurasiah Faqihsutan HRP, Meraih Hakikat Melalui Syariat: Telaah Pemikiran Syekh al-Akbar Ibn “Arabi (Bandung: Mizan, 2005), 133
} 


\section{PERBEDAAN AGAMA DALAM TIMBANGAN SUFISME}

Mengenai legalitas sesuatu mengenai aturan agama, Syekh Ahmad Sirhindi mengemukakan pandangan umumnya, yaitu: bahwa menjadi hukum shari'ah adalah apa yang dikemukakan di dalam al-Qur'an, al-Sunnah, Qiyas, dan Ijma'. Tidak ada prinsip lain dari keempat hal tersebut yang masih dianggap perlu untuk menetapkan legalitas suatu peratuaran. Ilham dan kasyaf sufi tidak dapat digunakan untuk menentukan apakah sesuatu itu salah atau benar. Ia hanya menjelaskan aturan yang sudah ditetapkan sebagai kebenaran, atau apa yang sesungguhnya merupakan perintah Allah yang pernah diturunkan pada seorang utusan-Nya. Para Wali mengikuti pendapat para Mujtahid, sebagaimana ummat Islam awam lainnya. ${ }^{19}$

Sementara itu, Ibn 'Arabi mengemukakan hal yang tak jauh berbeda, yakni; “ Malaikat tidak akan masuk ke dalam hati selain daripada rasul, dan tidak akan meniupkan perintah Allah. Shariah telah pasti, dan apa yang wajib, mandub, mubah, dan makruh telah dirumuskan. Tidak akan ada lagi tatanan baru dari Tuhan. Kenabian dan kerasulan sudah sampai pada akhir. Secara mutlak kita menolak kemungkinan adanya seseorang yang membawa (atau mengaku menerima) shariat baru, dan kemudian menyeru pada yang lain. Apabila ada seorang wali yang mendapatkan penglihatan kasyf, maka ia harus mengujinya dengan tuntunan al-Qur'an dan al-Sunnah. Apabila sesuai, maka ia dapat menganggapnya sebagai komunikasi antara kebenaran dan kehormatan, tetapi tidaklah lebih dari itu. Hal tersebut bukanlah tambahan (terhadap shariat) atau perintah (Tuhan) yang baru. Ia hanyalah menjelaskan suatu perintah, atau menjelaskan suatu pengertian. Ia akan dapat meningkatkan keyakinan sehingga menjadi pengetahuan. Apabila penglihatannya tidak meningkatkan keyakinannya sehingga menjadi pengetahuan. Apabila penglihatannya tidak sesuai dengan al-Qur'an dan Sunnah, walau ia mengakui kebenaran kenyataan tersebut, hendaklah dipandang sebagai cobaan. Tidaklah ada kemungkinan lain. Baginya tidak ada lagi perwujudan Malaikat atau iluminasi Ilahi. Kalau sampai muncul demikian, maka itu adalah penampakan shaitaniyyah. ${ }^{20}$

\footnotetext{
${ }^{19}$ Muhammad Abd. Haq Ahsan, Antara Sufisme dan Syari'ah: Kajian besar terhadap Sufisme Shekh Ahmad Sirhindi, (Jakarta: Rajawali Pers), 114

${ }^{20} \mathrm{Ibid}, 115$
} 
Dari hal di atas, terlihat bahwa para sufi hanya menyatakan kesesatan kepada orang yang mengadakan shari'at baru dalam Islam, tetapi mereka tidak menyatakan kesesatan kepada agama lain. Seperti pernyataan Ibn 'Arabi, bahwa shari' at yang dalam arti umum sebagai firman Tuhan yang diberikan kepada para Nabi sejak Nabi Adam a.s., hingga Nabi Muhammad SAW, yang kemudian menjelma ke dalam bentuk agamaagama sepanjang sejarah manusia adalah sama dari segi funsi dan tujuannya, yaitu menuntun aktivitas intelektual dan spiritual manusia dalam mengenal Allah, baik eksistensi-Nya, maupun segala hal yang berhubungan dengan hakikat Tuhan. ${ }^{21}$

Selain itu, shariat juga befungsi untuk menuntun aktifitas perealisasian pengetahuan atau kesadaran tentang Tuhan, yaitu keimanan itu sendiri. Karena semua sharia'at datang dari Tuhan yang satu, semua shariat adalah jalan Tuhan dan akan menggiring manusia kepada Tuhan. Jadi, fakta bahwa Tuhan adalah satu dan bahwa dunia ini adalah milik-Nya dan tercipta dari-Nya menimbulkan konsekwensi, bahwa tidak ada makhluk di dunia ini menyembah selain diri-Nya, dan bahwa tidak ada penyembahan yang tidak mengarah kepada-Nya. Namun, menurut Ibn 'Arabi, kenyataan ini hanya mungkin dipahami dan diterima oleh orang yang telah mencapai tahap ketinggian spiritual. ${ }^{22}$

Di sisi lain, dalam tradisi ahli fiqh, stigma sesat kadang tidak hanya dituju kan kepada orang yang dianggap menyimpang dari aturan shariat Islam, tetapi juga ditujukan kepada agama lain selain Islam.

Salah satu contoh dari stigma sesat kepada orang yang dianggap menyimpang dari aturan shariat Islam adalah pengkafiran terhadap Husain al-Hallaj, yang akhirnya divonis mati oleh Mahkamah Shar'iyah Baghdad pada tanggal 23 Zul Qa'dah $309 \mathrm{H}^{23}$ Contoh lainnya, stigma sesat terhadap agama lain, yaitu yang terjadi di Jogomulyo Jawa Tengah. Bagi umat Islam Jogomulyo, agama paling benar dihadapan Allah SWT hanya satu, yaitu Islam. Sedangkan agama lain diluar Islam adalah sesat. Tema-tema tersebut seringkali menjadi kegiatan di Jogomulyo dengan maksud membentengi umat Islam

\footnotetext{
${ }^{21}$ Nurasiah Faqihsutan HRP, Meraih Hakikat...., 72

22 Ibid, 75

23 Sa'id Abdul Fatah, Qissat al-Hallaj Wama Jara Maa Ahli Baghdad (terj.) Abdurrahim Ahmad, Di Ambang Kematian al-Hallaj: Tragedi Perjalanan Menuju Ma'rifat (Jakarta: Erlangga, 2009), 60
} 
supaya kian yakin akan kebenaran Islam, sehingga mereka tidak pindah agama dan tetap diikat dalam ikatan persaudaraan muslim (ukhuwah Islamiyah). ${ }^{24}$

Hal di atas, rupanya membawa dampak banyaknya peristiwa kekerasan atas nama agama di Jogomulyo, salah satunya yaitu pembakaran Wihara pada tanggal 28 April 1992/4 syawal 1414 M. Di Kebumen juga pernah terjadi peristiwa yang sama, karena Wihara menurut anggapan kalangan umat Islam diisukan sebagi pusat penyebaran agama Budha disana. Namun, dilain pihak, ummat Budha mensikapi tuduhan teologis dengan penuh hati-hati, lebih banyak diam dan tenang.

Menurut Hugh Goddard, sebagaimana dikutip oleh Budi Munawar-Rahman, adanya kecurigaan dan stigma sesat terhadap agama lain tersebut, dikarenakan adanya suatu kondisi "standar ganda". Maksudnya adalah, orang-orang beragama selalu menerapkan standar-standar yang berbeda untuk dirinya, yang biasanya standar yang bersifat ideal dan normatif untuk agama sendiri, sedangkan terhadap agama lain, memakai standar lain yang lebih bersifat realistis dan historis. ${ }^{25}$

Melalui standar ganda inilah, muncul prasangka-prasangka teologis, yang selanjutnya memperkeruh suasana hubungan antar umat beragama. Anggapan ada tidaknya keselamatan dalam agama lain, seringkali ditentukan oleh pandangan mengenai standar ganda kita. Dalam soal teologi misalnya, standar yang menimbulkan masalah klaim kebenaran adalah standar bahwa agama kita adalah agama yang paling sejati dari Tuhan, sedangkan agama lain hanya konstruksi manusia, atau mungkin juga berasal dari Tuhan, tapi telah dirusak, dipalsukan oleh ulah manusia. ${ }^{26}$

Pada dasarnya, penganut agama apapun kalau diiringi kesadaran bahwa ajaran agama sebagai satu-satunya kebenaran dan yang dapat menyelamatkan, maka kondisi standar ganda menjadi keniscayaan dalam interaksinya dengan penganut agama lain. Kalau berpijak pada pemikiran Mangkunegara IV, tentang bentuk-bentuk sembah sebagaimana di jelaskan diatas, bisa jadi apapun agamanya jika memuat bentuk-bentuk sembah, pasti semua agama akan benar-benar menjadi rahmat bagi sekian alam.

\footnotetext{
${ }^{24}$ Irwan Abdullah, dkk (editor), Dialektika Teks Suci Agama: Stukturasi Makna Agama dalam Kehidupan Masyarakat, (Yogyakarta: Pustaka Pelajar, 2008), 205

${ }^{25}$ Budi Munawar-Rahman, Islam Pluralis (Jakarta: Raja Grafindo Persada, 2004), 43

${ }^{26}$ Ibid, 44
} 


\section{KESIMPULAN}

Dari pembahasan di atas, nampaknya sebagaimana perbedaan sufisme dan ahli fiqh dalam melahirkan suatu hukum, terletak pada titik tekan yang berbeda. Dari tinjauan sufisme, yang telah disebutkan di atas terdapat satu kesamaan di antara mereka, yaitu bahwa para sufi, selain membahas hukum dari segi eksternal, mereka juga membahas semua aturan hukum fiqh dari segi batiniah, yang dianalisis dan diakaitkan dengan keberadaan jiwa spiritual manusia, sehingga mereka mampu menangkap inti tugas risalah Nabi SAW, yang akhirnya mampu melahirkan fiqh humanis (insaniah) yang lebih mengedepankan etika, dan mampu beradaptasi dengan seluruh lapisan masyarakat.

Sedangkan tinjauan fiqh, cendrung memandang dan memahami teks al-Qur'an dan Hadith secara tektual-literalis, yang hanya menekankan dimensi luarnya, dan kecendrungan memakai standar ganda dalam beragama, sehingga menghasilkan fiqh yang formalis strukturalis dan terlihat sangat kaku.

Perbedaan pandangan dan titik tekan, dan kecendrungan memakai standar ganda tersebut diatas, juga menyebabkan adanya perbedaan kriteria benar dan salah dalam agama. Para sufi terkesan sangat berhati-hati dalam menilai benar dan salah dalam agama, sedangkan ahli fiqh bisa dikatakan sangat mudah menilai benar dan salah dalam agama, hingga tidak hanya orang yang agamanya selain Islam yang mereka anggap sesat, melainkan juga orang yang seagama, tapi secara terapan fiqh berbeda tidak luput dari anggapan sesat.

\section{DAFTAR PUSTAKA}

Ali Ahmad Sa'id Asbar (Adonis), Sejarah-Pemikiran Arab-Islam, (Yogyakarta: LKiS, 2007).

Al-Kalabadzi, al-Ta’aruf li Mazahib Ahlal-Tasawuf (terj.) Rahmani Astuti, Ajaran Kaum Sufi (Bandung: Mizan, 1993)

Budi Munawar-Rahman, Islam Pluralis (Jakarta: Raja Grafindo Persada, 2004)

Muhammad Ibn"Abbad, Letter On The Sufi Parth (terj.) M.S. Nasrullah, Surat-Surat Sang Sufi (Bangdung: Mizan,1993)

https://id.wikipedia.org/wiki/Mangkunegara_IV, diakses tanggal 24 Oktober 2017

Harun Nasution, Pembaharuan dalam Islam (Jakarta: Bulan Bintang, 1973) 
Hudhari Bik, Tarikh Tashri' al-Islami (terj) Mohammad Zuhri, Sejarah Pembinaan Hukum Islam, (Semarang: Darul Ikhya, 1980)

HR. Abu Hurairah

Irwan Abdullah, dkk (editor), Dialektika Teks Suci Agama: Stukturasi Makna Agama dalam Kehidupan Masyarakat, (Yogyakarta: Pustaka Pelajar, 2008)

Jaih Mubarak, Kaidah Fiqh: Sejarah dan Kaidah Asasi, (Jakarta: Raja Grafindo, 2002)

Moh. Ardani, al-Qur'an dan Sufisme Mangkunegara IV (Studi Serat-serat Piwulang), (Yogyakarta: Dana Bhakti Wakaf, 1995)

Mahmud Shaltut, Al-Islam Aqidah wa Shari'ah (Mesiri: Dar Al-Qalam,1996)

Nurasiah Faqihsutan HRP, Meraih Hakikat Melalui Syariat: Telaah Pemikiran Syekh alAkbar Ibn "Arabi (Bandung: Mizan, 2005)

Muhammad Abd. Haq Ahsan, Antara Sufisme dan Syari'ah: Kajian besar terhadap Sufisme Shekh Ahmad Sirhindi, (Jakarta: Rajawali Pers, 2008)

Sa'id Abdul Fatah, Qissat al-Hallaj Wama Jara Maa Ahli Baghdad (terj.) Abdurrahim Ahmad, Di Ambang Kematian al-Hallaj: Tragedi Perjalanan Menuju Ma'rifat (Jakarta: Erlangga, 2009)

Shahih Al-Bukhari no. 43 